\title{
BAHASA FIGURATIF DALAM NOVEL SUPERNOVA KARYA DEWI LESTARI : PENDEKATAN STILISTIKA
}

\author{
Heleri Mariani Sinabutar, Ikhwanuddin Nasution, Eddy Setia \\ Universitas Sumatera Utara \\ helerisinabutar@gmail.com/085275229351
}

\begin{abstract}
ABSTRAK
Bahasa Figuratif dalam Novel Supernova Karya Dewi Lestari: Pendekatan Stilistika ini merupakan analisis penggunaan bahasa di dalam novel tersebut. Penelitian ini bertujuan melihat aspek kebahasaan dalam karya sastra. Penelitian ini merupakan penelitian deskriptif kualitatif dengan tujuan mendeskripsikan pemilihan dan penggunaan gaya bahasa figuratif yang meliputi idiom, metafora, simile, personifikasi, dan hiperbola, yang terdapat dalam novel Supernova. Data penelitian ini berupa kata, frasa dan kalimat yang diambil dari dua seri novel Supernova yaitu Kesatria Putri dan Bintang Jatuh dan Intelegensi Embun Pagi. Teknik pengumpulan data menggunakan teknik pustaka, simak dan catat. Teknik analisis data yaitu dengan analisis mengalir yang terjadi secara bersamaan, yaitu reduksi data, penyajian data dan penarikan kesimpulan. Selanjutnya penelitian ini menggunakan metode distribusional yang dijabarkan lewat teknik substitusi dan teknik pelesapan. Hasil penelitian menunjukkan bahwa penggunaan gaya bahasa figuratif yang unik menimbulkan efek estetis pada pembaca yaitu penggunaan idiom, metafora, simile, personifikasi dan hiperbola. Hal tersebut menunjukkan bahwa Dewi Lestari sebagai penulis mampu menunjukkan pemanfaatan bahasa yang spesifik dan lain dari yang lain dalam menciptakan karya sastra. Hal tesebut menghasilkan style tersendiri yang menjadi ciri khusus Dewi Lestari dalam menuangkan gagasannya melalui novel Supernova.
\end{abstract}

Kata Kunci : stilistika, diksi, figuratif.

\section{A. PENDAhULUAN}

Dalam menciptakan karya sastra, baik novel, prosa, puisi maupun drama, seorang pengarang tentunya menggunakan bahasa sebagai mediumnya. Setiap pengarang selalu memiliki ciri khas dalam penulisan karyanya. Beberapa faktor yang membuat seorang penulis menjadi khas adalah tentang pilihan kata (diksi) dan gaya bahasa figuratif yang digunakan dalam karya sastra tersebut. Penggunaan bahasa yang khas dalam setiap karya akan memperlihatkan sisi atau gaya masing-masing dari penulis. Salah satu penulis yang sudah dikenal banyak orang dengan kekhasan penggunaan bahasa dalam karyanya adalah Dewi Lestari, melalui novelnya Supernova

Setiap pengarang tentu memiliki konsep berbeda-beda dalam menciptakan atau melahirkan karya sastra. Hal ini disebabkan karena adanya berbagai keanekaragaman dan style tiap penulis. Gaya kepenulisan Dewi Lestari melalui novelnya Supernova sangat menarik untuk diteliti. Novel Supernova ditulis dengan gaya yang realis bertabur metafora yang tidak biasa namun mampu memikat pembaca untuk terus membaca dan mendalami novel tersebut. Perhatikan kutipan berikut ini. 
Sampai percikan miliaran cahaya perlahan datang, menjadikan gelap tadi bening. Bening sejernih tetes embun pagi pertama di Taman Firdaus. (KPBJ : 291)

Debur ombak berubah menjadi menakutkan. Sinar matahari menusuk tajam dan perih di kulit. (IEP : 348)

Berdasarkan kutipan di atas, dapat dilihat bahwa Dewi Lestari mampu menggunakan bahasa dengan metafora yang memikat. Novel Supernova seri pertama Kesatria, Putri dan Bintang Jatuh (KPBJ) dan seri terakhir Intelegensi Embun Pagi (IEP) terdapat kutipan yang mengandung bahasa figuratif.

Selanjutnya salah satu cara untuk mengetahui gaya penulisan setiap pengarang adalah dengan meneliti kekhasan dan keunikan penggunaan bahasa yang digunakan setiap penulis dalam membuat karya-karyanya. Pengkajian mengenai kekhasan dan keunikan pemakaian bahasa tersebut adalah untuk menemukan dan menandai ciri umum karya seorang penulis. Kemudian ilmu yang tepat untuk mengkaji penggunaan bahasa dalam karya sastra dengan pendekatan secara linguistik adalah stilistika.

Kajian stilistika ini merupakan pengkajian karya sastra yang berorientasi linguistik atau penggunaan parameter linguistik dalam mengkaji karya sastra. Titik berat kajian stilistika itu sendiri memang terletak pada penggunaan bahasa dan gaya bahasa suatu karya sastra. Menurut Ratna (2007 : 236) stilistika dapat didefenisikan sebagai : Ilmu tentang gaya bahasa. Ilmu Interdisipliner antara linguistik dengan sastra. Ilmu tentang penerapan kaidah-kaidah linguistik dalam penelitian gaya bahasa, Ilmu yang menyelidiki pemakaian bahasa dalam karya sastra dan Ilmu yang menyelidiki pemakaian bahasa dalam karya sastra, dengan mempertimbangkan aspek-aspek keindahannya sekaligus latar belakang sosialnya.

Pemilihan Novel Supernova Karya Dewi Lestari didasarkan pada temuan bahwa bahasa figuratif yang menarik untuk dikaji lebih jauh. Penulis tertarik terhadap karyakarya pengarang Dewi Lestari yang selalu mendapat predikat Best Seller, mendapat penghargaan di ajang nasional ataupun internasional. Dewi Lestari adalah salah satu penulis yang tidak mengikuti pangsa pasar seperti novel remaja kebanyakan, novel metropop, novel remaja yang mudah diketahui alurnya, menggunakan bahasa yang mudah dimengerti. Walau tidak mengikuti pangsa pasar, bahasanya tidak mudah 
dimengerti, namun Dewi Lestari mampu menyihir masyarakat untuk selalu menantikan karyanya. Inilah hal unik dari karya Dewi Lestari, dan tentu ini tidak terlepas dari diksi dan gaya bahasa yang digunakan Dewi Lestari dalam karyanya.

Dalam Jurnal Sastra Indonesia yang diterbitkan oleh Universitas Negeri Semarang pada November 2013, terdapat penelitian stilistika dalam bentuk artikel yang ditulis oleh Syaiful Munir dkk. Penelitian tersebut berjudul Diksi dan Majas dalam Kumpulan Puisis Nyanyian dalam Kelam karya Sutikno W.S : Kajian Stilistika. Tujuan penelitiannya yaitu untuk mengetahui penggunaan diksi dan majas serta fungsinya. Dalam metode penelitian digunakan pendekatan stilistika dengan cara menganalisis sistem linguistik karya sastra dan dilanjutkan dengan mengintrepretasi ciri-cirinya dilihat dari tujuan estetis karya sastra sebagai keseluruhan makna. Adapun hasilnya berupa pembuktian adanya wujud diksi dan majas (Munir, Saiful dkk. 2013).

Martini Girsang (2014) dengan judul Stilistika dan Kesetaraan Gender Dalam Lirik Lagu Batak Toba. Penelitian ini adalah sebuah penelitian stilistika yang berhubungan dengan style, yang difokuskan pada ciri, cara dan gaya bahasa yang terkandung dalam 10 (sepuluh) lirik lagu Batak Toba. Tujuan penelitian ini adalah menemukan style yang berhubungan dengan ciri, cara dan gaya bahasa; peran, tanggung jawab dan perjuangan perempuan Batak Toba; serta menghubungkannya dengan ideologi masyarakat Batak Toba, hasangapon, hamoraon, hagabeon; menemukan peran perempuan Batak Toba yang dapat menolak konstruksi pendapat beberapa filsuf; yang tergambar melalui sepuluh lirik lagu Batak Toba.

Hal inilah yang mendorong penulis mengadakan penelitian tentang bahasa yang digunakan Dewi Lestari dalam meyampaikan makna dan pesan cerita melalui bahasa figuratif dalam novel Supernova. Dalam hal ini, penulis memilih dua seri yang menjadi acuan untuk melihat Bahasa Figuratif yang terdapat dalam Supernova yaitu seri pertama Kesatria Putri \& Bintang Jatuh (KPBJ) dan seri keenam atau terakhir Intelegensi Embun Pagi (IEP).

\section{B. KAJIAN TEORI}

\section{Stilistika}


Menurut Ratna (2010 : 3), stilistika adalah suatu ilmu yang mempelajari tentang gaya, sementara stil (style) yaitu tentang cara-cara yang khas bagaimana segala sesuatu diungkapkan dengan cara tertentu, sehingga tujuan yang dimaksudkan dapat dicapai secara maksimal. Stilistika dalam hal ini berhubungan dengan majas, yaitu perumpamaan atau kiasan.

Stilistika adalah ilmu yang meneliti penggunaan bahasa dan gaya bahasa di dalam karya sastra. Stilistika merupakan sebuah proses dalam menganalisis karya sastra dengan melihat bagaimana unsur-unsur bahasa sebagai medium karya sastra digunakan sastrawan sehingga terlihat bagaimana perlakuan sasstrawan terhadap bahasa dalam rangka menuangkan gagasannya. Oleh sebab itu, semua proses yang berhubungan dengan analisis bahasa karya sastra dimaksudkan untuk mengungkapkan aspek kebahasaan dalam karya tersebut, seperti diksi, penggunaan bahasa kias, bahasa piguratif, struktur kalimat, bentuk-bentuk wacana, dan sarana retorika lainnya.

\section{Bahasa Figuratif}

Bahasa figuratif adalah bahasa yang digunakan untuk menyatakan suatu makna dengan cara tidak biasa atau tidak sesuai dengan yang diucapkan. Bahasa figuratif ini digunakan oleh para penyair untuk mengatakan sesuatu dengan cara yang tidak langsung untuk mengungkapkan makna. Fakta-fakta dan pernyataan-pernyataan dapat diungkapkan dengan buatan tidak alami atau artifisial.

Keindahan bahasa figuratif terdapat pada unsur fonologi, morfologi, sintaksis, leksikon, maupun gaya ungkap. Keindahan hasil budi manusia yang tetulis maupun tidak tertulis dapat diketahui melalui gaya bahasa yang digunakannya. Penggunaan gaya bahasa yang setepat-tepatnya akan dapat menarik atau menggetarkan hati pembaca untuk mengaguminya.

\section{a. Idiom}

Idiom merupakan konstruksi dari unsur-unsur yang saling memilih, masingmasing anggota mempunyai makna yang ada hanya karena bersama yang lain. Idiom juga diartikan konstruksi yang maknanya tidak sama dengan gabungan makna anggotaanggotanya (Kridalaksana, 2008: 72). 
Idiom adalah penggunaan kata atau kelompok kata secara unik, karena artinya tidak dapat dirunut secara langsung dari unsur-unsur pembentuk kata atau kelompok kata tersebut. Kelompok kata di sini dapat terdiri dari dua atau tiga unsur yang dianggap sebagai unit tunggal. Bentuk idiom ini tidak dapat dialih bahasakan ke dalam bahasa lain. Contoh : Dia adalah perempuan yang keras kepala

Pada contoh di atas kata keras kepala merupakan idiom, yang artinya tidak mau menurut nasihat orang lain, dalam hal ini kata tersebut memiliki arti jika bersama-sama, artinya maknanya tidak dapat diartikan dari makna leksikal unsur-unsurnya.

\section{b. Metafora}

Metafora adalah semacam analogi yang membandingkan dua hal secara langsung, tetapi dalam bentuk yang singkat: Metafora sebagai perbandingan langsung tidak mempergunakan kata: seperti bak, bagai, bagaikan, dan sebagainya.

Contoh : Si lintah darat itu datang lagi.

Kalimat diatas adalah perbandingan langsung seseorang yang disamakan dengan lintah darat. Kalimat diatas tidak menggunakan bak, bagai, bagaikan sebagai pembangding, melainkan langsung membuat perbandingan dua analogi. Dimana lintah darat artinya adalah rentenir yang dibandingan sama halnya dengan lintah.

\section{c. Simile}

Simile atau persamaan adalah perbandingan yang bersifat eksplisit. Perbandingan bersifat eksplisit mempunyai maksud bahwa ia langsung menyatakan sesuatu sama dengan hal yang lain. Adapun fungsi penggunaan gaya bahasa simile yaitu sebagai sarana retorika yang mampu menghidupkan lukisan dan menyegarkan pengungkapan. Jelasnya dengan penggunaan simile pengungkapan maksud menjadi lebih mengesankan, lebih hidup, dan lebih menarik. Simile membandingkan dua hal dengan kata depan dan penghubung, seperti layaknya, bagaikan, umpama, ibarat, bak, bagai.

Contoh : hatinya lembut bagai salju

Dari contoh diatas dapat dilihat perbandingannya bersifat eksplisit atau langsung, hatinya lembut disamakan dengan salju yang juga bersifat lembut. 


\section{d. Personifikasi}

Personifikasi adalah gaya bahasa kiasan yang menggambarkan benda-benda mati atau barang-barang yang tidak bernyawa seolah-olah memiliki sifat kemanusiaan. Hal itu tidak terlepas dari fungsi personifikasi itu sendiri yaitu sebagai sarana retorika yang mampu menghidupkan lukisan dan menyegarkan pengungkapan.

Contoh : Kereta api tua itu meraung-raung ditengah kesunyian malam

Dalam contoh diatas dapat kita lihat bahwa kereta api yang merupakan benda mati seolah olah digambarkan sebagai manusia yang bisa meraung-raung.

\section{e. Hiperbola}

Hiperbola adalah gaya bahasa yang mengandung suatu pernyataan yang berlebihan, dengan membesar-besarkan sesuatu hal. Bentuk Hiperbola itu melukiskan betapa sesuatu dibesar-besarkan, namun demikian tetap menarik. Jelasnya dengan penggunaan hiperbola, pengungkapan maksud menjadi lebih mengesankan, lebih hidup, lebih indah dan lebih menarik. Contoh : Suaranya sampai ke langit ketujuh

Kalimat diatas menunjukkan ungkapan yang berlebihan, suara seseorang yang terlalu besar diungkapkan bisa sampai kelangit ketujuh.

\section{METODE PENELITIAN}

Penelitian ini adalah Penelitian linguistik terhadap karya sastra yang berhubungan dengan Stilistika, yaitu ilmu yang mempelajari tentang style, bagaimana segala sesuatu diungkapkan dengan ciri, cara dan gaya tertentu dan yang mempunyai keterkaitan dengan gaya bahasa sehingga tujuan yang hendak dicapai dapat disampaikan secara maksimal.

Ditinjau dari jenis datanya pendekatan penelitian yang digunakan dalam penelitian ini adalah pendekatan kualitatif. Adapun yang dimaksud dengan penelitian kualitatif yaitu penelitian yang bermaksud untuk memahami fenomena tentang apa yang dialami oleh subjek penelitian secara holistik, dan dengan cara deskripsi dalam bentuk kata-kata dan bahasa, pada suatu konteks khusus yang alamiah dan dengan memanfaatkan berbagai metode ilmiah Moleong (2005:6). 
Data diambil dari kedua seri novel Supernova yaitu Kesatria Putri dan Bintang Jatuh dan Intelegensi Embun Pagi yang sesuai dengan objek yang akan dianalisis. Data kemudian dianalisis, ditampilkan dalam bentuk uraian kata-kata berupa deskriptif. Teknik analisis data yang dipergunakan ada dua, yaitu 1) teknik substitusi, dan 2) teknik pelesapan atau delisi (Sudaryanto, $2015: 42-43$ ).

\section{HASIL DAN PEMBAHASAN}

\section{Penggunaan Bahasa Figuratif yang Terdapat dalam Novel Supernova karya Dewi Lestari}

Sebuah karya sastra terutama novel pasti banyak ditemukan penggunaan bahasa figuratif. Hal tersebut tidak terlepas dari fungsi bahasa figuratif itu sendiri yaitu sebagai sarana retorika yang mampu menghidupkan lukisan dan menyegarkan pengungkapan. Dengan penggunaan bahasa figuratif pengungkapan maksud menjadi lebih mengesankan, lebih hidup, lebih jelas dan lebih menarik. Penggunaan bahasa figuratif terdapat dalam novel Supernova baik seri pertama Kesatria Putri dan Bintang Jatuh dan seri terakhir Intelegensi Embun Pagi. Berikut beberapa bahasa figuratif yang terdapat pada novel Supernova.

\section{a. Idiom}

Idiom adalah konstruksi yang maknanya tidak sama dengan gabungan makna unsurnya. Adapun penggunaan idiom pada novel Supernova karya Dewi Lestari adalah dapat dilihat pada data-data berikut ini.

1. Untuk sebuah konflik kisah cinta, haruskah kapasitas seorang Avatar yang turun tangan ? (KPBJ : 17)

2. Nggak ada kapoknya itu orang-orang, gumam Re. Cukup terkesan akan sikapnya yang tidak langsung menolak mentah. (KPBJ : 28)

3. Sekalipun sopir-sopir bus sudah hafal luar kepala setiap belokan, perjalanan itu akan beda apabila ditempuh dengan pesawat. (KPBJ : 59)

Pemilihan dan penggunaan idiom pada data-data di atas dalam deskripsi cerita dimaksudkan penulis untuk lebih memperdalam makna tuturan. Idiom-idiom tersebut sangat mewarnai dalam deskripsi cerita sehingga kalimat-kalimat yang ditulis Dewi Lestari membuat pembaca dibuatnya terlena dan larut dalam cerita dengan untaian bahasa yang begitu memikat. Selain itu pemilihan dan penggunaan idiom berfungsi 
untuk membuat indah deskripsi cerita. Jika makna sebenarnya langsung dituangkan dalam kalimat tentu akan membuat deskripsi cerita menjadi monoton.

Penggunaan Idiom juga terdapat dalam novel Supernova seri terakhir Intelegensi Embun Pagi. Idiom adalah konstruksi yang maknanya tidak sama dengan gabungan makna unsurnya. Adapun penggunaan idiom pada novel Supernova Intelegensi Embun Pagi karya Dewi Lestari dapat dilihat pada data-data berikut ini.

4. Setahuku, retret Ayahuasca bisa makan waktu berhari-hari. Apa yang bisa kudapat dengan satu kali minum? (IEP : 17)

5. Mudah-mudahan yang kubilang ini bakal bikin kamu sedikit lebih lega: patah hati adalah bagian dari paket wajib kalian sebagai Peretas," jawab Luca. (IEP : 30)

Data-data di atas menunjukkan penggunaan idiom. Data (4) menunjukkan penggunaan idiom makan waktu yang artinya adalah menghabiskan waktu. Data (5) menunjukkan menggunaan idiom patah hati yang artinya adalah perasaan sakit hati karena tidak sesuai dengan yang diharapkan.

\section{b. Metafora}

Metafora adalah semacam analogi yang membandingkan dua hal secara langsung. Metafora sebagai perbandingan langsung tidak mempergunakan kata pembanding: seperti, bak, bagai, bagaikan, dan sebagainya. Adapun penggunaan gaya bahasa metafora terdapat dalam novel Supernova baik seri pertama Supernova Kesatria Putri dan Bintang Jatuh maupun seri terakhir Intelegensi Embun Pagi. Penggunaan metafora dalam novel Supernova Kesatria Putri dan Bintang Jatuh dapat diperhatikan pada data berikut.

6. Reuben menyambut tangan itu, terasa halus, sehalus paras dan penampilan orangnya yang terawat. (KPBJ :2)

7. Berbeda dengan dirinya, guratan wajah yang tegas, setegas jabat tangannya. (KPBJ :2)

Data di atas dikategorikan sebagai bentuk metafora karena dalam kalimat tersebut terdapat dua hal yang dibandingkan secara langsung seolah-olah sama dengan hal lain yang digunakan sebagai pembanding. Data (6) tangan yang halus dibandingkan dengan paras halus, artinya paras/wajahnya juga halus sama dengan tangannya yang juga halus. Data (7) menunjukkan wajah yang tegas disamakan dengan jabat tangan yang juga tegas. 
Penggunaan gaya bahasa metafora juga terdapat dalam novel Supernova Intelegensi Embun Pagi. Perhatikan data berikut.

8. Omongan Luca terasa segetir cairan Ayahuasca. (IEP : 27)

9. Tampak Toni melompat ringan dari pintu angkot segesit kernet. (IEP : 38)

Data-data di atas menunjukkan penggunaan metafora. Pada data (8) omongan tokoh Luca yang membuat getir disamakan dengan cairan Ayahuasca yang ketika diminum juga terasa getir. Data (9) menunjukkan penggunaan metafora dimana Toni yang gesit dibandingkan langsung dengan kernet yang juga gesit.

\section{c. Simile}

Simile adalah perbandingan yang bersifat eksplisit. Perbandingan bersifat eksplisit mempunyai maksud bahwa ia langsung menyatakan sesuatu sama dengan hal yang lain. Pemanfaatan gaya bahasa bentuk simile ditandai dengan kata pembanding seperti, seumpama, laksana, bak, bagaikan selayaknya dan sebagainya. Penggunaan Simile terdapat dalam novel Supernova Kesatria Putri dan Bintang Jatuh dan Intelegensi Embun Pagi.

10. Sejarah yang satu ini... ah, seperti melukis di air. (KPBJ : 5)

11. Suara Rana mengambang seperti awan. (KPBJ : 40)

12. Bagai polimer elastis, ia juga amat mudah diarahkan. (KPBJ :72)

13. Ia menerobos kerumunan orang yang tengah meliuk-liuk bagai kumpulan lidah api sedang membakar diri mereka sendiri. (KPBJ :72)

14. Di atrium, panggung itu berdiri dengan dekorasi bak kue tar murahan. (KPBJ : 81)

Pada data (10) sejarah yang digambarkan diibaratkan dengan melukis di air yang artinya tidak akan pernah ada karena akan selalu tergenang air. Data (11) menunjukkan suara yang mengambang disamakan sengan awan yang juga mengambang dilangit. Pada data (12) seseorang yang mudah diarahkan diibaratkan seperti polimer yang elastis. Polimer yang elastis tentu memang mudah diarahkan. Data (13) menunjukkan keadaan seseorang yang meliuk-liuk disamakan dengan lidah api yang membakar diri mereka sendiri yang artinya dimana keadaan yang meliuk liuk seperti orang yang terbakar dengan api, bergerak gerak dengan cepat. Pada data (14) di atas menunjukkan keadaan panggung yang didekorasi sama halnya dengan kue tar murahan yang artinya tidak cantik. 
Penggunaan Simile juga terdapat dalam novel Supernova Intelegensi Embun Pagi. Adapun penggunaan simile pada novel Supernova Intelegensi Embun Pagi karya Dewi Lestari dapat dibedakan dari kata pembandingnya. Berikut ini data penggunaan simile

15. Kamu seperti rockstar di panggung konser, semua lampu menyorotmu, dan kamu jadi target empuk untuk diburu. (IEP : 13)

16. Gua hitamm lalu terkuak di hadapannya, memanjang seperti terowongan tak berujung. (IEP : 21)

17. Ia hanya menuangkan Ayahuasca ke mangkuk kosong, lalu meminumnya dengan elegan bagai menyeruput teh hangat dari cangkir porselen. "(IEP : 19)

18. Tak hanya melihat, Gio merasakan fisiknya melenyap. Tidak ada lagi rasa berat dan solid. Mengawang bagai molekul udara. (IEP : 23)

19. Watti yang bertingkah laku bak seorang putri di tengah kerajaan rongsokan. (IEP : 671)

Pendeskripsian cerita dengan menggunakan bahasa figuratif simile membuat pembaca seolah olah ada di posisi tersebut, bisa merasakan apa yang dituangkan dalam cerita. Sebagai contoh pada data (15) ) ketika Gio meminum ayahuasca diibaratkan akan merasakan perasaan seperti seorang rockstar dimana akan menjadi sorotan utama. Pada data (16) menceritakan sebuah gua yang memanjang disamakan dengan terowongan tak berujung-kita tahu bahwa itu artinya adalah gua nya sangatlah panjang. Pada data (17) kata pembanding bagai digunakan untuk membandingkan meminum dengan elegan diibaratkan dengan menyeruput teh hangat dari porselen dan kita tahu porselen sangat berharga sehingga seseorang yang minum dari porselen menjadi elegan karna menikmati minum dan penuh kehati-hatian. Data (18) menjukkan mengawang diibaratkan dengan molekul udara yang juga mengawang di udara. Data (19) menunjukkan penghubung bak yang mengibaratkan tingkah laku wati seperti Putri di kerajaan rongsokan yang artinya kerajaan yang tidak ada artinya atau tidaklah seperti kerajaan yang biasanya penuh kemegahan.

Dari uraian di atas dapat dilihat bahwa Dewi Lestari banyak menggunakan Bahasa Figuratif Simile dengan kata penghubung seperti, bagai, bagaikan dan bak. Penggunaan bahasa figuratif simile menandakan pemanfaatan bahasa dalam menciptakan karya sastra. Penempatan bahasa Figurati Simile menjadikan deskripsi cerita lebih hidup dan menarik. 


\section{d. Personifikasi}

Personifikasi adalah gaya bahasa kiasan yang menggambarkan benda-benda mati atau barang-barang yang tidak bernyawa seolah-olah memiliki sifat kemanusiaan. Personifikasi terdapat dalam novel Supernova baik Kesatria Putri dan Bintang Jatuh maupun Intelegensi Embun Pagi. Perhatikan kutipan berikut ini.

20. Satu semesta mungil yang mampu melumat bumi. (KPBJ : 25)

21. Karena rinduku menetas sebanyak tetes gerimis. (KPBJ : 106)

22. Tiupan seruling. Meliuk lincah dan merdu menembus dinginnya petang di puncak bukit. (IEP :7)

23. Sekejap ia menghilang ditelan setapak gelap. (IEP :9)

Pada data (20) di atas menunjukkan semesta yang digambarkan seolah-olah melumat bumi, padahal kata melumat merupakan keadaan yang hanya bisa dilakukan makluk hidup yaitu manusia. Data (21) menunjukkan keadaan rindu yang digambarkan menetas, padahal menetas adalah tingkahlaku makhluk hidup yaitu hewan. Pada data (22) tiupan seruling diibaratkan bisa meliuk seperti manusia. Data (23) setapak gelap diibaratkan bisa menelan manusia.

Penggunaan gaya bahasa personifikasi menunjukkan pemanfaatan bahasa dalam sarana beretorika, memperindah suasana penceritaan dalam novel. Dewi lestari mampu menempatkan bahasa dalam deskripsi cerita, sehingga cerita semakin menarik dan pengungkapan suatu peristiwa lebih bermakna.

\section{e. Hiperbola}

Hiperbola adalah gaya bahasa yang mengandung suatu pernyataan yang berlebihan dengan membesar-besarkan sesuatu hal. Penggunaan hiperbola terdapat dalam novel Supernova Kesatria Putri dan Bintang Jatuh dan Intelegensi Embun Pagi. Perhatikan data berikut.

24. Ia menawari Kesatria untuk mampu melesat secepat cahaya. (KPBJ : 36)

25. Selelah orang disuruh menggusur gunung, ia pun tidak tahan lagi. Mulai menangis. (KPBJ : 93)

26. Namun, ibunya tidak memperhitungkan muatan emosi yang pampat memenuhi setiap sudut dan celah, yang tidak bisa Zarah bersihkan meski ia memboyong seribu sapu dan kain pel sekalipun. (IEP : 184)

27. Otot-ototnya ringan seperti baru diurut pemijat terbaik dunia. (IEP : 263) 
Pemilihan kosakata menggunakan hiperbola oleh Dewi Lestari dimaksudkan untuk mendeskripsikan cerita agar lebih dirasakan oleh pembaca. Data (24) menunjukkan keadaan melesat secepat cahaya. Hal ini merupakan keadaan yang berlebihan, dimana kecepatan cahaya 299792458 meter per detik yang tidak akan mungkin bisa dilakukan oleh manusia. Data (25) menunjukkan keadaan selelah menggeser gunung dimana hal tersebut merupakan hal yang berlebihan. Menggeser gunung adalah hal yang tidak mungkin bisa dilakukan manusia. Pada data (26) terdapat penggunaan hiperbola yaitu pada keadaan memboyong seribu sapu dan kain pel sekalipun untuk membersihkan rumah. Hal tersebut menunjukkan keadaan yang berlebiham, karena dengan satu kain pel dan sapu pun bisa membersihkan seluruh bagian rumah. Data (27) menunjukkan penggunaan hiperbola dimana keadaan otot yang ringan seperti diurut pemijat terbaik dunia. Hal ini menggabarkan keadaan yang berlebihan, karena tidak ada indikasi seseorang atau ukuran seseorang menjadi pemijat terbaik dunia.

Penggunaan hiperbola dalam deskripsi cerita membuat keadaan cerita lebih hidup. Penggabaran dengan hiperbola membuat pembaca seolah ikut merasakan apa yang dirasakan tokoh. Dengan penggunaan hiperbola yang tepat, pengungkapan makna lebih hidup dan lebih menarik.

Hasil penelitian di atas, dapat disimpulkan dalam tabel berikut.

\begin{tabular}{|c|l|l|}
\hline No & \multicolumn{1}{|c|}{ Data } & Identifikasi \\
\hline 1. & $\begin{array}{l}\text { Untuk sebuah konflik kisah cinta, haruskah kapasitas } \\
\text { seorang Avatar yang turun tangan? (KPBJ : 17) }\end{array}$ & Idiom \\
\hline 2. & $\begin{array}{l}\text { Nggak ada kapoknya itu orang-orang, gumam Re. } \\
\text { Cukup terkesan akan sikapnya yang tidak langsung } \\
\text { menolak mentah. (KPBJ : 28) }\end{array}$ & Idiom \\
\hline 3. & $\begin{array}{l}\text { Sekalipun sopir-sopir bus sudah hafal luar kepala } \\
\text { setiap belokan, perjalanan itu akan beda apabila } \\
\text { ditempuh dengan pesawat. (KPBJ : 59) }\end{array}$ & Idiom \\
\hline 4. & $\begin{array}{l}\text { Setahuku, retret Ayahuasca bisa makan waktu berhari- } \\
\text { hari. Apa yang bisa kudapat dengan satu kali minum? } \\
\text { (IEP : 17) }\end{array}$ & Idiom \\
\hline 5. & $\begin{array}{l}\text { Mudah-mudahan yang kubilang ini bakal bikin kamu } \\
\text { sedikit lebih lega: patah hati adalah bagian dari paket } \\
\text { wajib kalian sebagai Peretas," jawab Luca. (IEP : 30) }\end{array}$ & Idiom \\
\hline
\end{tabular}




\begin{tabular}{|c|c|c|}
\hline 6. & $\begin{array}{l}\text { Reuben menyambut tangan itu, terasa halus, sehalus } \\
\text { paras dan penampilan orangnya yang terawat. (KPBJ } \\
\text { :2) }\end{array}$ & Metafora \\
\hline 7. & $\begin{array}{l}\text { Berbeda dengan dirinya, guratan wajah yang tegas, } \\
\text { setegas jabat tangannya. (KPBJ :2) }\end{array}$ & Metafora \\
\hline 8. & $\begin{array}{l}\text { Omongan Luca terasa segetir cairan Ayahuasca. (IEP } \\
\text { 27) }\end{array}$ & Metafora \\
\hline 9. & $\begin{array}{l}\text { Tampak Toni melompat ringan dari pintu angkot } \\
\text { segesit kernet. (IEP : 38) }\end{array}$ & Metafora \\
\hline 10. & $\begin{array}{l}\text { Sejarah yang satu ini... ah, seperti melukis di air. } \\
\text { (KPBJ : 5) }\end{array}$ & Simile \\
\hline 11. & Suara Rana mengambang seperti awan. (KPBJ : 40) & Simile \\
\hline 12. & $\begin{array}{l}\text { Bagai polimer elastis, ia juga amat mudah diarahkan. } \\
\text { (KPBJ :72) }\end{array}$ & Simile \\
\hline 13. & $\begin{array}{l}\text { Ia menerobos kerumunan orang yang tengah meliuk- } \\
\text { liuk bagai kumpulan lidah api sedang membakar diri } \\
\text { mereka sendiri. (KPBJ :72) }\end{array}$ & Simile \\
\hline 14. & $\begin{array}{l}\text { Di atrium, panggung itu berdiri dengan dekorasi bak } \\
\text { kue tar murahan. (KPBJ : 81) }\end{array}$ & Simile \\
\hline 15. & $\begin{array}{l}\text { Kamu seperti rockstar di panggung konser, semua } \\
\text { lampu menyorotmu, dan kamu jadi target empuk untuk } \\
\text { diburu. (IEP : 13) }\end{array}$ & Simile \\
\hline 16. & $\begin{array}{l}\text { Gua hitam lalu terkuak di hadapannya, memanjang } \\
\text { seperti terowongan tak berujung. (IEP : 21) }\end{array}$ & Simile \\
\hline 17. & $\begin{array}{l}\text { Ia hanya menuangkan Ayahuasca ke mangkuk kosong, } \\
\text { lalu meminumnya dengan elegan bagai menyeruput teh } \\
\text { hangat dari cangkir porselen. "(IEP : 19) }\end{array}$ & Simile \\
\hline 18. & $\begin{array}{l}\text { Tak hanya melihat, Gio merasakan fisiknya melenyap. } \\
\text { Tidak ada lagi rasa berat dan solid. Mengawang bagai } \\
\text { molekul udara. (IEP }: 23 \text { ) }\end{array}$ & Simile \\
\hline 19. & $\begin{array}{l}\text { Watti yang bertingkah laku } b a k \text { seorang putri di tengah } \\
\text { kerajaan rongsokan. (IEP : 671) }\end{array}$ & Simile \\
\hline 20. & $\begin{array}{l}\text { Satu semesta mungil yang mampu melumat bumi. } \\
(\text { KPBJ : 25) }\end{array}$ & Personifikasi \\
\hline
\end{tabular}




\begin{tabular}{|c|l|l|}
\hline 21. & $\begin{array}{l}\text { Karena rinduku menetas sebanyak tetes gerimis. (KPBJ } \\
: 106)\end{array}$ & Personifikasi \\
\hline 22. & $\begin{array}{l}\text { Tiupan seruling. Meliuk lincah dan merdu menembus } \\
\text { dinginnya petang di puncak bukit. (IEP :7) }\end{array}$ & Personifikasi \\
\hline 23. & Sekejap ia menghilang ditelan setapak gelap. (IEP :9) & Personifikasi \\
\hline 24. & $\begin{array}{l}\text { Ia menawari Kesatria untuk mampu melesat secepat } \\
\text { cahaya. (KPBJ : 36) }\end{array}$ & Hiperbola \\
\hline 25. & $\begin{array}{l}\text { Setelah orang disuruh menggusur gunung, ia pun tidak } \\
\text { tahan lagi. Mulai menangis. (KPBJ : 93) }\end{array}$ & Hiperbola \\
\hline 26. & $\begin{array}{l}\text { Namun, ibunya tidak memperhitungkan muatan emosi } \\
\text { yang pampat memenuhi setiap sudut dan celah, yang } \\
\text { tidak bisa Zarah bersihkan meski ia memboyong seribu } \\
\text { sapu dan kain pel sekalipun. (IEP : 184) }\end{array}$ & Hiperbola \\
\hline 27. & $\begin{array}{l}\text { Otot-ototnya ringan seperti baru diurut pemijat terbaik } \\
\text { dunia. (IEP : 263) }\end{array}$ & Hiperbola \\
\hline
\end{tabular}

\section{E. KESIMPULAN}

Berdasarkan hasil analisis dalam pembahasan dapat disimpulkan

- Keunikan dan kekhasan penggunaan bahasa pada novel Supernova Kesatria Putri dan Bintang Jatuh dan Intelegensi Embun Pagi dipengaruhi oleh latar belakang pendidikan penulis faktor sosial budaya yang diungkapkan penulis dalam deskripsi ceritanya.

- Dalam kedua novel Supernova terdapat Penggunaan bahasa figuratif pada novel Supernova baik dalam Kesatria Putri dan Bintang Jatuh maupun Intelegensi Embun Pagi membuat pendeskripsian cerita menjadi lebih hidup, lebih jelas, tidak membosankan sehingga membuat cerita lebih menarik.

- Beberapa penggunaan bahasa figuratif yang terdapat dalam pembahasan novel Supernova yaitu, idiom, metafora, simile, personifikasi, dan hiperbola. Penggunaan bahasa figuratf menimbulkan efek estetis pada pembaca. Dewi Lestari memilih dan memanfaatkan kosakata figuratif yang disesuaikan dengan makna dalam kalimat. 


\section{F. SARAN}

Penelitian Stilistika terhadapa novel sangat penting peranannya pada kemajuan studi stilistika di Indonesia. Studi stilistika mampu menemukan perihal kebahasaan dan kesusastraan sebagai objeknya. Kajian stilistika terhadap karya sastra novel Supernova masih terbuka untuk diteliti lebih lanjut karna penulis menyadari bahwa penelitian ini masih ada kekurangan.

\section{DAFTAR PUSTAKA}

Girsang, M. 2014. Stilistika Dan Kesetaraan Gender Dalam Lirik Lagu Batak Toba. Medan. Universitas Sumatera Utara Press.

Keraf, G. 2008. Diksi dan Gaya Bahasa. Jakarta: Gramedia.

Kridalaksana, H. 2008. Kamus Linguistik. Gramedia : Jakarta.

Lestari, D. 2012. Supernova (Kesatria Putri dan Bintang Jatuh). Yogyakarta : Bentang Pustaka

Lestari, D. 2016. Supernova (Intelegensi Embun Pagi). Yogyakarta : Bentang Pustaka.

Moleong, L.Y. 2007. Metode Penelitian Kualitatif. Bandung : Reaja Karya.

Ratna, N. K. 2004. Penelitian Sastra, Teori, Metode dan Teknik. Yogyakarta : Pustaka Pelajar.

Ratna, N. K. 2007. Metodologi Penelitian Kajian Budaya dan Ilmu Sosial Humaniora pada Umumnya. Yogyakarta : Pustaka Pelajar

Ratna, N.K. 2009. Stilistika. Kajian Puitika Bahasa, Sastra dan Budaya. Yogyakarta: Pustaka Pelajar.

Sudaryanto. 2016. Metode dan Aneka Teknik Analisis Bahasa. Yogyakarta : Sanata Dharma University Press.

Syaifur, M. dkk. 2013 : "Diksi dan Majas dalam Kumpulan Puisis Nyanyian dalam Kelam karya Sutikno W.S : Kajian Stilistika". Jurnal Sastra Indonesia Universitas Negeri Semarang.

Verhaar. 2001. Asas-Asas Linguistik Umum. Yogyakarta: Universitas Gadjah Mada Press.

Wellek, R dan Austin W. 2014. Teori Kesusastraan. (Terj. Melani Budianta). Jakarta : Gramedia 